\title{
LOUVAIN \\ NATURAL RADIOCARBON MEASUREMENTS III
}

\author{
E. GILOT, N. ANCION and P. C. CAPRON
}

Department of Nuclear Chemistry, University of Louvain, Louvain, Belgium

The following list covers the samples measured at the Louvain $\mathrm{C}^{14}$ dating laboratory in 1964 .

\section{INTRODUCTION}

All the measurements were made with the 0.6- $\mathrm{L} \mathrm{CH}_{+}$proportional counter, operating at $3 \mathrm{~atm}$ pressure. Ages are calculated on the basis of a $\mathrm{C}^{14}$ half life of $5570 \mathrm{yr}$. As a modern carbon standard, we use wood taken from A.D. 1870 to A.D. 1900 tree rings.

Errors include the experimental standard deviation on the counting rate of the background, of the modern standard and of the unknown sample (Crèvecoeur, Vander Stricht and Capron, 1959) .

No changes were made in the chemical pretreatment and $\mathrm{CH}_{4}$ preparation. The procedure has been described in Lourain I.

\section{ACKNOWLEDGMENTS}

We are pleased to acknowledge the assistance of F. Frix in routine operation and chemical preparations. Our thanks are also due to G. Michotte for maintenance of electronics.

The description of each sample is based on information provided by the person submitting the sample to the laboratory. Financial support was provided by the Institut Interuniversitaire des Sciences Nucléaires.

\section{Terneuzen series}

\section{SAMPLE DESCRIPTIONS}

Peat and wood from fossil pine stand at Terneuzen $\left(51^{\circ} 19^{\prime} \mathrm{N}\right.$ Lat, $3^{\circ}$ 48’ E Long), Zeeuws Vlanderen, The Netherlands, alt sealevel. The trunks were covered by Sub-Boreal peat, $150 \mathrm{~cm}$ thick, under Sub-Atlantic clay, $100 \mathrm{~cm}$ thick. Coll. 1962 and subm. by A. Munaut, Univ. of Louvain, Lab. of Palynology and Dendrochronology.

General Comment: the following series represent a continuation of the program to test the dendrochronologic method in the Terneuzen site (see Louvain II, Lv-114 to Lv-120).

\section{Lv-121. Terneuzen 15-20 cm}

$3260 \pm 110$ 1310 в.с.

Peat from 15 to $20 \mathrm{~cm}$ below surface of peat layer. Sub-Boreal level. Comment (A.M.) : pollen analysis shows Fagus content larger than $1 \%$.

\section{Lv-122. Terneuzen $42-48 \mathrm{~cm}$}

$3750 \pm 100$

1800 в.с.

Peat from 42 to $48 \mathrm{~cm}$ below surface of peat layer. Sub-Boreal level. Comment (A.M.) : at that level comes the 4th hazel maximum (Corylus avel- 
lana-C III), before the decrease of Ulmus dated as 3500 B.P. in Louvain II (Lv-118).

\section{Lv-123. Terneuzen $75-80 \mathrm{~cm}$}

Peat from 75 to $80 \mathrm{~cm}$ below surface of peat layer. Atlantic level. Comment (A.M.) : end of the local increase of Pinus. Date seems too old according to the other dates.

\section{Lv-124. Terneuzen 97-102 $\mathrm{cm}$}

$4560 \pm 110$

2610 B.C.

Peat from 97 to $102 \mathrm{~cm}$ below surface of peat layer. Atlantic level. Comment (A.M.) : beginning of the local increase of Pinus.

Lv-128. Terneuzen pine B 14

$4120 \pm 100$

2170 B.c.

Wood from pine trunk (Pinus silvestris, id. by E. Frison) from peat 180 $\mathrm{cm}$ below ground surface. Sample is taken between 1st and 20th growth ring.

\section{Lv-125. Terneuzen pine B 11}

$4010 \pm 130$ 2060 в.c.

Wood taken between 205th and 225th growth ring of the same pine as Lv-128.

\section{Lv-126. Terneuzen oak B 12}

$4530 \pm 110$

2580 B.C.

Wood from oak trunk (Quercus, id. by E. Frison) lying under the pines, from peat $180 \mathrm{~cm}$ below ground surface.

\section{Lv-127. Terneuzen pine B 13}

$4120 \pm 100$ 2170 в.c.

Wood from pine trunk (Pinus silvestris, id. by E. Frison) from peat 180 cm below ground surface.

\section{Lv-129. Terneuzen pine B 16}

$4700 \pm 120$ 2750 в.C.

Wood from pine trunk (Pinus silvestris, id. by E. Frison) from peat 180 $\mathrm{cm}$ below ground surface. Comment (A.M.) : date seems a little too old according to the dendrochronology.

\section{Lv-132. Terneuzen oak B 15}

$4550 \pm 160$ 2600 B.c.

Wood from oak trunk (Quercus, id. by E. Frison) lying under the pines, from peat $180 \mathrm{~cm}$ below ground surface.

\section{Lv-51. Anlier II}

$4850 \pm 150$

2900 B.C.

Peat from Fange des Beutiers $\left(33^{\circ} 10^{\prime} \mathrm{N}\right.$ Lat, $5^{\circ} 35^{\prime} \mathrm{E}$ Long), at Rulles, Prov. of Luxembourg. Belgium, alt $440 \mathrm{~m}$. Sample is taken at depth of 130 to $160 \mathrm{~cm}$ below ground surface. Coll. 1962 and subm. by W. Mullenders, Univ. of Louvain, Lab. of Palynology. Comment (W.M.) : pollen analysis shows hazel increase (Corylus avellana) with decrease of Ulmus; considering thickness of sample, date agrees with a level a little younger than CX. At same level, presence of corn pollen indicates the Neolithic culture of Michelsberg. 


\section{Dunes of Westhoek series}

Humic matter from De Panne $\left(51^{\circ} 05^{\prime} \mathrm{N}\right.$ Lat, $2^{\circ} 33^{\prime} \mathrm{E}$ Long), Prov. of West-Vlaanderen, Belgium, alt $9.60 \mathrm{~m}$. Horizon below the wind-blown dunes of XVIth and XVIIth centuries. Coll. 1963 and subm. by F. Depuydt, Univ. of Louvain, Geol. Inst.

\section{Lv-173. Westhoek 340-360 $\mathrm{cm}$}

Sample from 340 to $360 \mathrm{~cm}$ below ground surface.

$$
\text { A.D. } 1400
$$

\section{Lv-174. Westhoek 255-270 cm}

$$
\mathbf{3 7 0} \pm \mathbf{7 0}
$$

Sample from 255 to $270 \mathrm{~cm}$ below ground surface.

\section{Ordona series}

II. ARCHAEOLOGIC SAMPLES

Charcoal from Ordona $\left(41^{\circ} 18^{\prime} \mathrm{N}\right.$ Lat, $15^{\circ} 37^{\prime}$ E Long), Prov. of Foggia, Italy. Coll. and subm. by J. Mertens, Univ. of Louvain, Archaeol. Inst.

$$
2070 \pm 70
$$

\section{B.C.}

Charcoal from oldest layers of the ancient Roman colony at Herdoniae, now Ordona.

\section{Lv-176.}

Charcoal from same level as Lv-175.

\section{Lv-177.}

\section{A.D. 50}

Charcoal from a burned horizon leveled while constructing a section of Via Appia across southern Italy.

\section{Lv-178.}

Charcoal from same level as Lv-177.

$$
1930 \pm 100
$$

\section{Lv-181. Bouillon}

Wood from "Godefroid" room in feudal castle at Bouillon (49 $47^{\prime} \mathrm{N}$ Lat, 5 04' E Long), Prov. of Luxembourg, Belgium. Coll. 1963 by F. Bourgeois, Service des Fouilles, Brussels; subm. by J. Mertens. Date confirms the previously found modern age of the cross found in that room (Lv-50, Louvain II).

\section{Lv-30. Sainte Marie}

$$
1860 \pm 80
$$

Wood from Roman road at Sainte Marie $\left(49^{\circ} 55^{\prime} \mathrm{N}\right.$ Lat, $5^{\circ} 29^{\prime} \mathrm{E}$ Long), Prov. of Luxembourg, Belgium, alt $479 \mathrm{~m}$. Sample is taken at $0.60 \mathrm{~m}$ depth. Coll. and subm. by J. Mertens, Service des Fouilles, Brussels.

\section{Lv-41. Les Causses

Dept. of Aveyron, France, alt $800 \mathrm{~m}$. Cont. 1960 by 
Mullenders. Resin was contained in an urn, probably Gallo-Roman, found at depth of $0.30 \mathrm{~cm}$ inside a dolomite stone circle. Comment: resin was treated with $\mathrm{HCl}$, but not with $\mathrm{NaOH}$, because of its solubility. Culturally, according to the urn characteristics, date seems too old.

\section{Lv-104. Collège de la Sainte Trinité}

Wood from lime stub in situ (Tilia, id. by E. Frison) in garden of College de la Sainte Trinité at Louvain $\left(50^{\circ} 53^{\prime} \mathrm{N}\right.$ Lat, $4^{\circ} 41^{\prime} \mathrm{E}$ Long), Prov. of Brabant, Belgium. Coll. 1963 and subm. by A. Vander Stricht, Univ. of Louvain. The stub was found near remains of arches, probably a cellar, along ruins of a sewer, showing the site to have been a by-street, now destroyed.

\section{Leopoldville series}

Samples related to prehistoric industries in the Leopoldville plain (van Moorsel, 1956; De Ploey, 1963). Coll. by H. van Moorsel, Prehistorical Mus., Lovanium Univ., Leopoldville, Congo; subm. by F. Gullentops, Univ. of Louvain.

\section{Lv-162. Mont Gafula}

Charcoal from Mont Gafula ( $4^{\circ} 28^{\prime} \mathrm{S}$ Lat, $15^{\circ} 13^{\prime} \mathrm{E}$ Long), Prov. of Leopoldville, Congo, alt $600 \mathrm{~m}$. Sample is taken at depth of $2 \mathrm{~m}$, in eolian yellow sand, from a stone-working factory characteristic of late Tshitolian. A sample from same level (Lv-45, Louvain I and II) was dated as 5830 B.P.

\section{Lv-163. Basoko 3}

Charcoal from valley of Basoko River ( $4^{\circ} 21^{\prime} \mathrm{S}$ Lat, $15^{\circ} 17^{\prime} \mathrm{E}$ Long), Prov. of Leopoldville, Congo. Charcoal was imbedded in muddy yellow sand at $30 \mathrm{~cm}$ above the sandstone layer. At the same level, Lupembian stone industry. Date agrees with Lv-47 (Louvain I and II) from same level.

\section{Lv-164. Basoko 2}

$9730 \pm 200$

7780 в.C.

Sample from same site as Lv-163. Charcoal coll. from a Tshitolian horizon in the clay bank of the river.

\section{Lv-165. Cabu 4}

$8920 \pm 160$

Charcoal from valley of Belgika River $\left(4^{\circ} 20^{\prime} \mathrm{S}\right.$ Lat, $15^{\circ} 19^{\prime} \mathrm{E}$ Long), Prov. of Leopoldville, Congo, alt $308 \mathrm{~m}$. Fireplace with Tshitolian industry in rlayey sand at depth of $0.60 \mathrm{~m}$ below ground surface.

\section{Lv-166. Cabu 5}

$15,080 \pm 480$ 13,130 в.c.

Charcoal from same site as Cabu 4, but at depth of $2 \mathrm{~m}$ below ground surface, just above the sandstone layer. With the charcoal, middle Lupembian industry.

\section{Lv-167. Funa}

$$
\begin{gathered}
2220 \pm 90 \\
270 \text { в.C. }
\end{gathered}
$$

Charcoal from the sources of Funa River ( $4^{\circ} 26^{\prime} \mathrm{S}$ Lat, $15^{\circ} 18^{\prime} \mathrm{E}$ Long), Prov. of Leopoldville, Congo. Sample is from hearth buried together with a 
few potsherds at $1.10 \mathrm{~m}$ depth in humic layer $2 \mathrm{~m}$ thick which overlies the sandstone layer. Just on the sandstone, Tshitolian industry.

\section{Lv-168. Ile des Mimosas}

Charcoal from Ile des Mimosas $\left(4^{\circ} 20^{\prime} \mathrm{S}\right.$ Lat, $15^{\circ} 14^{\prime} \mathrm{E}$ Long $)$, in the Congo, Prov. of Leopoldville, Congo. Charcoal together with old potsherds in the humic layer above the fluviatile sand overlying the red sandstone blocks.

Date lists:

\section{Referejces}

Louvain I Dossin, Deumer and Capron, 1962

Louvain II Deumer, Gilot and Capron, 1964

Archéologie, 1961, Sainte-Marje-Chévigny: p. 169.

Archéologie, 1964, Sainte-Marie-Chévigny: villa romaine, p. 17.

Ardenne et Famenne, 1963, La croix énigmatique du château-fort de Bouillon: v. 6, p. 85 87.

Crèvecoeur, E. H., Vander Stricht, A., and Capron, P. C., 1959, Precision of the dating method. Standardization of the calculation of the errors and the maximum age in the $\mathrm{C}^{14}$ method: Acad. Royale Belgique Bull. C. Sci., v. 45, 1. 876-890.

De Ploey, J., 1963, Quelques indices sur l'évolution morphologique et paléoclimatique des environs du Stanley-Pool (Congo): Univ. Lovanium Studia Fac. Sci., no. 17, 16 p.

De Ploey, J., and van Moorsel, H., 1963, Contributions à la connaissance chronologique et paléogéographique des gisements préhistoriques des environs du Stanley-Pool (Congo): Univ. Lovanium Studia Fac. Sci., no. 19, 19 p.

Mertens, J., 1964a, Richerche archaeologiche ad Ordona. Rapporto provvisorio sulla campagna del 1962/63: Notizie dei Scavi. v. 16, p. 1-29.

- 1964b, Recherches archéologiques à Ordona (Antique Herdoniae en Apulie, Italie), Rapport sur les travaux entrepris en 1962 et 1963: Accad. Naz. dei Lincei Rendiconti, v. 19, p. 110-116.

Mertens, J., Iker, R., and De Boe, G., in press, Ordona, Fouilles belges en Italie

Munaut, A., 1963, La forêt fossile de Terneuzen: Soc. Royale Bot. Bull., v. 96, fasc. 2, p. 456.

van Moorsel, H., 1956, Esquisse préhistorique de la plaine de Léopoldville: Acad. Royale Sci. Coloniales Belgique, ser. II, fasc. 4, p. 582-595, 19 pl. 